\title{
SCIDiC
}

\author{
International Journal of Dentistry and Oral Science (IJDOS) \\ ISSN: 2377-8075
}

\section{Association of Age and Gender with Cast Post Restoration in Maxillary Central Incisors after Endodontic Treatment}

Research Article

Preetha Parthasarathy ${ }^{1}$, Delphine Priscilla Antony $\mathrm{S}^{2 *}$, Sreedevi Dharman ${ }^{3}$

${ }^{1}$ Saveetha Dental College and Hospital, Saveetha Institute of Medical and Technical Sciences [SIMATS], Saveetha University, Chennai 600077, Tamil $\mathrm{Nadu}$, India.

${ }^{2}$ Senior Lecturer, Department of Conservative and Endodontics, Saveetha Dental College and Hospital, Saveetha Institute of Medical and Technical Sciences [SIMATS], Saveetha University, Chennai 600077, Tamil Nadu, India.

${ }^{3}$ Reader, Department of Oral medicine and Radiology, Saveetha Dental College and Hospital, Saveetha Institute of Medical and Technical Sciences [SIMATS], Saveetha University, Chennai 600077, Tamil Nadu, India.

Abstract

Endodontically treated tooth with extensive coronal tooth structure loss, requires additional retention and is restored with post and core system. Post is a metal restorative material placed in the radicular part of the tooth and core is a substructure that replaces the coronal tooth structure. The purpose of this study is to find a correlation between age and gender in cast post restorations. The aim of this study is to evaluate the association between age and gender with cast post restoration in maxillary central incisors. The study was done in an university set up - Saveetha Dental College, Chennai. A retrospective study was conducted in patients with cast post restoration in maxillary central incisors. The data was collected from the hospital digital database by reviewing the patient's records and analysing them. Simple random sampling was done to minimize sampling bias. After reviewing, the case sheets were filtered based on data required. The final sample size was 43 patients with cast post restoration in maxillary central incisors. It was observed that, higher frequency of cast post restoration was noted in male population- $44.1 \%$ in tooth number 11 and $27.9 \%$ in 21 . The age group 18-35years [39.53\%] had a high prevalence of cast post restoration done in 11 . The $\mathrm{P}$ value was found to be statistically not significant [0.917] which is $>0.05$. Within the limits of the study, it was observed that cast post restoration was more prevalent among male population and at the age group of 20years. The most commonly affected tooth was 11 . Thus, the study can be used as a reference in understanding the most commonly affected age group with anterior teeth damage.

Keywords: Core; Post; Metal; Root Canal System; Endodontic Treatment.

\section{Introduction}

An endodontically treated tooth with extensive coronal tooth structure damage, where additional retention is required, is usually restored with post and core system [39]. A post is a metal restorative material or any other rigid restorative material that is placed in the radicular portion of an endodontically treated tooth. Core refers to a properly shaped substructure which replaces the missing coronal structure and retains the final restoration.

Endodontic posts are classified in various ways, namely the preformed and custom-made cast, metallic and nonmetallic, aesthetic and non-aesthetic [7]. The main function of a post and core is to improve resistance to lateral force by distributing the force over a large area [36].

When a post is indicated in an extensively damaged tooth, it should be placed in the largest and preferably, in the straightest canal, so that weakening of root during post preparation is avoided [17]. Distal canal in the mandibular molar and palatal canal in maxillary molar are considered for post-placement. Post type can be metallic or non-metallic. The metallic post is classified into custom cast post and pre-fabricated post and nonmetallic post are classified into carbon fibre post, fibre reinforced post and ceramic

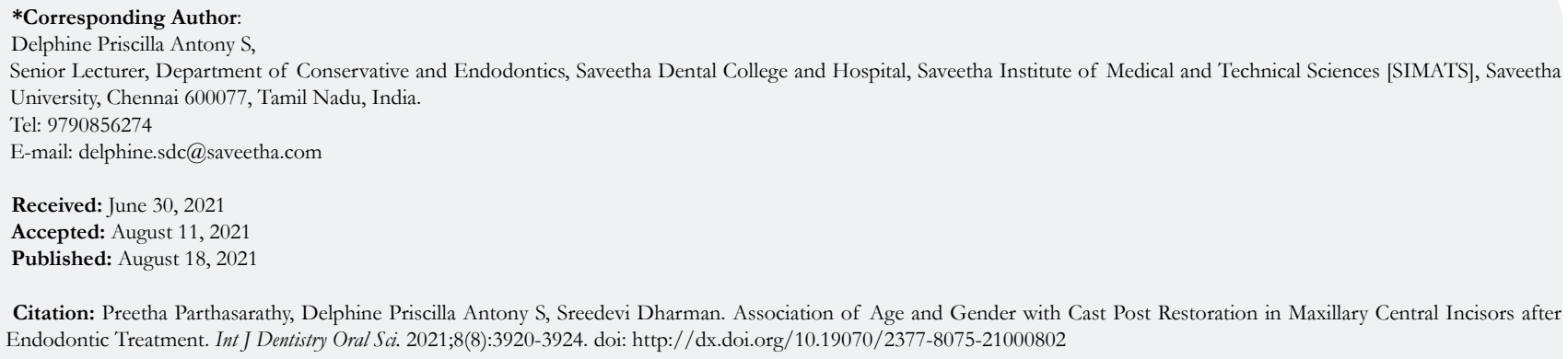

Citation: Preetha Parthasarathy, Delphine Priscilla Antony S, Sreedevi Dharman. Association of Age and Gender with Cast Post Restoration in Maxillary Central Incisors after Endodontic Treatment. Int J Dentistry Oral Sci. 2021;8(8):3920-3924. doi: http://dx.doi.org/10.19070/2377-8075-21000802

Copyright: Delphine Priscilla Antony S 2021. This is an open-access article distributed under the terms of the Creative Commons Attribution License, which permits unrestricted use, distribution and reproduction in any medium, provided the original author and source are credited. 
and zirconia post.

The custom-made cast post uses either gold alloys, chrome cobalt alloys or nickel chromium alloys. Advantages of a cast post system over a prefabricated post are that they are custom fit to the root configuration. They are adaptable to largely irregularly shaped canals and orifices and they can be adapted to be used with prefabricated plastic pattern [6]. The major disadvantage of cast post system is that it requires two or more appointments and temporisation between appointments gets difficult [13].

The endodontic treatment done also plays a key role in preventing further damage to the restored tooth. The type of material used in endodontic therapy is important. Extrusion of precipitate from the intracanal irrigants can lead to periapical tissue damage and inflammation [41]. In inflammatory conditions the MMP-3 levels can be high [44]. To prevent extrusion, irrigation with $5.25 \%$ sodium hypochlorite is done intermittently,1-2 mm short of apex [43]. Chlorhexidine can be used in all steps of root canal treatment due to its substantivity property [22]. Novamin is a bioactive glass that adheres to the exposed dentin and forms a mineralised layer thus preventing further progression of the dental caries [29].

The study was carried out to find a correlation between age and gender in cast post restorations. Previously our team has a rich experience in working on various research projects across multiple disciplines. (Jain, 2017 [14]); (Varghese, Ramesh and Veeraiyan, 2019 [45]); (Ashok and Ganapathy, 2019 [2]); Padavala and Sukumaran, 2018 [23]); (Ke et al., 2019 [18]); (Ezhilarasan, 2018 [9]); (Krishnan et al., 2018 [19]); (Ezhilarasan, Sokal and Najimi, 2018 [11]); (Pandian, Krishnan and Kumar, 2018 [25]); (Ramamurthy and Mg, 2018 [32]); (Gupta, Ariga and Deogade, 2018 [12]); (Vikram et al., 2017 [49]); (Paramasivam, Vijayashree Priyadharsini and Raghunandhakumar, 2020 [48]); (Palati et al., 2020 [24]); (Samuel, Acharya and Rao, 2020 [38]). Now the growing trend in this area motivated us to pursue this project.

The aim of the study is to evaluate association of age and gender with post-restoration in maxillary central incisor after endodontic treatment.

\section{Materials and Methods}

\section{Study Setting:}

This study was based on data collected from the digital database of Saveetha Dental College and Hospitals. Patient's records were reviewed and analyzed between June 2019 to March 2020. The study protocol was approved by the Institute Review Board under ethical approval number SDC/SIHEC/2020/DIASDATA/0619-0320. Two examiners were included in the study.

\section{Sampling:}

Data was collected retrospectively over a nine month period spanning from June 2019 to March 2020. Cross verification of data for error was done by additional reviewers and by photographic evaluation. Simple random sampling was done to minimize sampling bias. After reviewing, the case sheets were filtered based on data required. The final sample size was 43 patients with cast post restoration in maxillary central incisors.

\section{Data collection:}

The data was entered in the system in a methodical manner. For the present study, patient's records were obtained from the hospital digital database. The data was entered in excel manually and imported to SPSS for analysis. Chi-square test was performed. The level of significance was set at 0.05 . Incomplete data was excluded from the study.

\section{Analytics:}

IBM SPSS Software [Version: 23 IBM Corporation NY USA] was used for data analysis. Descriptive statistics which included frequency of distribution was used for analysis.

\section{Results \& Discussion}

The collected data was entered in SPSS version 23 and variables were assigned. Chi square test was used to tabulate the result. From the collected data, it was observed that cast post restoration was done in maxillary central incisors that were more common in male population. It was found that tooth number 11 had a prevalence of male population- $44.1 \%$ and in female population it was $23.2 \%$. In tooth number 21 , the prevalence in males was $27.9 \%$ and in females were $4.6 \%$. [Table: 1 Graph: 1].Association between age and cast post restoration in maxillary central incisors was studied. It was observed that the age group 18-35 years had more incidence of cast post restoration done in 11 [39.53\%] [Graph:2]. The mean age group observed was 34.67 years. The $\mathrm{P}$ value was found to be insignificant $>0.05$ [Table: 2$]$.

From the present study, it has been observed that male population

\footnotetext{
Figure 1: Bar graph showing association between gender and cast post restoration in maxillary central incisors [11, 21]. The $X$ axis denotes gender and $\mathrm{Y}$ axis denotes number of patients with cast post restoration. It is observed that male patients had more prevalence of cast post restoration done in tooth -11 [blue] than in tooth - 21 [green]. However, the association was not statistically significant [Pearson Chi square value- 1.914, df-1, p value-0.166: $\mathrm{p}>0.05$.
}

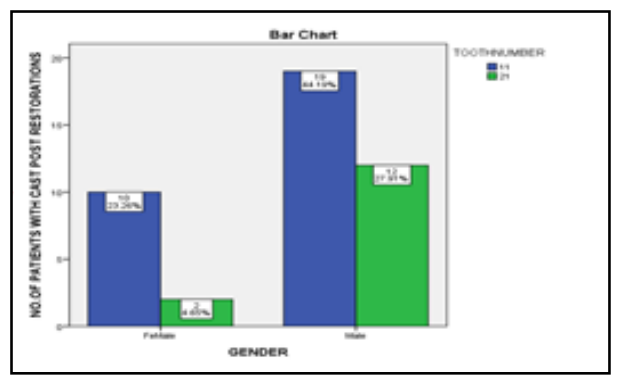


Table 1: The table shows frequency distribution between males and females who had undergone cast post restorations in maxillary central incisors [11, 21]. It was observed that males had a higher prevalence of cast post restoration in maxillary central incisors [72.1\%].

\begin{tabular}{|c|c|c|c|}
\hline Gender & $\begin{array}{l}\text { Tooth } \\
\text { num- } \\
\text { ber-11 }\end{array}$ & $\begin{array}{l}\text { Tooth } \\
\text { num- } \\
\text { ber-21 }\end{array}$ & Total \\
\hline Female & \multirow[b]{2}{*}{10} & \multirow[b]{2}{*}{2} & \multirow[b]{2}{*}{12} \\
\hline Count & & & \\
\hline$\%$ of total & $23.30 \%$ & $4.70 \%$ & $27.90 \%$ \\
\hline Male & \multirow[b]{2}{*}{19} & \multirow[b]{2}{*}{12} & \multirow[b]{2}{*}{31} \\
\hline Count & & & \\
\hline$\%$ of total & $44.20 \%$ & $27.90 \%$ & $72.10 \%$ \\
\hline Total & \multirow[b]{2}{*}{29} & \multirow[b]{2}{*}{14} & \multirow[b]{2}{*}{43} \\
\hline Count & & & \\
\hline$\%$ of total & $67.40 \%$ & $32.60 \%$ & $100 \%$ \\
\hline
\end{tabular}

Table 2: The table shows Pearson Chi-square analysis of gender of the patients with cast post restoration in maxillary central incisors. Asymptotic significance value obtained was 0.166 . Thus, the Chi- square test shows $P$ value to be statistically not significant [ $>0.05]$.

\begin{tabular}{|c|c|c|c|}
\hline $\begin{array}{c}\text { Statistical } \\
\text { analysis }\end{array}$ & value & df & $\begin{array}{c}\text { Asymptotic } \\
\text { significance } \\
\text { [2-sided] }\end{array}$ \\
\hline $\begin{array}{c}\text { Pearson } \\
\text { Chi- } \\
\text { Square }\end{array}$ & 1.914 & 1 & 0.166 \\
\hline $\begin{array}{c}\text { Likeli- } \\
\text { hood ratio }\end{array}$ & 2.072 & 1 & 0.15 \\
\hline $\begin{array}{c}\text { N of valid } \\
\text { cases }\end{array}$ & 43 & & \\
\hline
\end{tabular}

Figure 2: Bar graph showing association between age and cast post restoration in maxillary central incisors [11,21]. The $X$ axis denotes age and $\mathrm{Y}$ axis denotes number of patients with cast post restoration. It is observed that patients in the age group of 18-35 years had undergone cast post restoration in 11 [blue] than in 21 [green]. However, the association was not statistically significant [ Pearson Chi square value- $0.173, \mathrm{df}-2, \mathrm{p}$ value-0.917]. . ince $\mathrm{p}>0.05$.

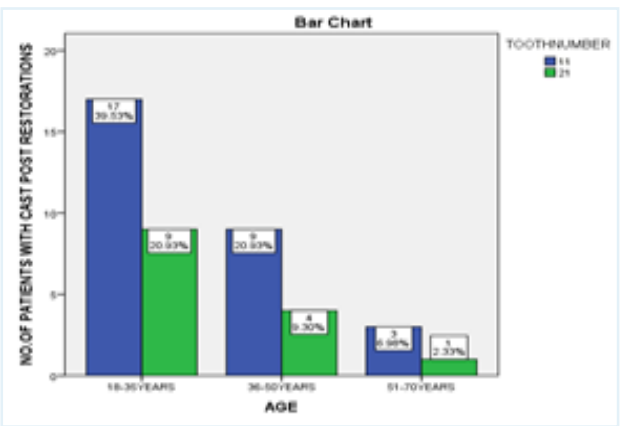

had a higher frequency of cast post restorations, $44.1 \%$ in 11 and $27.9 \%$ in 21 . This can be related to increased incidence of trauma to the maxillary anterior teeth due to their exposed position in the dental arch [4]. More incidence of cast post restoration done in the female population was seen in $11-23.2 \%$. The age group $18-35$ years had prevalence for $11-39.53 \%$.

In shashikala $\mathrm{K}$ et al's study, the mean age observed was 37.17 years which is in accordance to the present study [40]. Maria A et al, in their study, has found that female prevalence observed was $64.3 \%$, whereas in males the prevalence was $35.7 \%$. The mean age group was 52.5 years [1]. The present study is in contrast to Maria A et al's study. Our study shows high prevalence noted in male population and the mean age group to be 34.67 years.
Markins B et al., has observed that the female population had an incidence of $50.6 \%$ and males had $49.4 \%$ incidence of cast post restorations. The mean age group was found to be 50.1 years [3]. The current study shows a contrast; the prevalence was more in male population with mean age 34.6 years.

Pentzfeldt A et al., in their study, studied that the frequency of fracture of cast post restoration was more in male population-24\% and in females it was 13\%. (Peutzfeldt, Sahafi and Asmussen, 2008) 28. In a study conducted by Ennesto B et al, the gender difference was found to be statistically insignificant and did not affect the outcome of the study. The mean age was 63.9 years (Ernesto Borgia, Rosario Barón and José Luis Borgia, no date) which is in contrast to our study. 
Few studies have discussed various technologies and techniques used in endodontic therapy such as in the management of dental traumatic injuries [16], techniques adapted in intra canal medicament usage [20]. Few studies have shown that grape seed extract has better remineralizing effect [46].

The efficiency of ProTaper universal and Protaper Next was studied, and was found to cause higher thinning of root dentin [33]. In few studies, the pulse oximeter was found to be more accurate followed by cold and heat testing [15]. The usage of Endoactivator has shown to have lesser post-operative pain among patients [31].

Considering the previous literature, the present study is not in accordance with it. The difference can be attributed to limited sample size and other factors such as longevity of tye material, fracture resistance was not assessed. Therefore, further studies with large sample size and other parameters to be carried out for better view on the prevalence.

Our institution is passionate about high quality evidence based research and has excelled in various fields ( (Pc, Marimuthu and Devadoss, 2018 [27]; Ramesh et al., 2018 [34]; Vijayashree Priyadharsini, Smiline Girija and Paramasivam, 2018 [34]; Ezhilarasan, Apoorva and Ashok Vardhan, 2019 [10]; Ramadurai et al., 2019 [30]; Sridharan et al., 2019 [42]; Vijayashree Priyadharsini, 2019 [47]; Chandrasekar et al., 2020 [5]; Mathew et al., 2020 [21]; R et al., 2020 [35]; Samuel, 2021 [37]). We hope this study adds to this rich legacy.

\section{Conclusion}

Within the limits of the study, it was observed that the cast post restoration was more prevalent in male patients [72.1\%] and the commonly affected tooth was 11 . The age group $18-35$ years had more frequency of cast post restorations done in tooth 11 .

\section{References}

[1]. Amaral M, Coppo PP, Rosalem CG, Suaid FF, Guerra SM. A 3-Year Retrospective Evaluation of the Clinical Performance of Fiber Posts. Braz Dent J. 2015 Nov-Dec;26(6):619-23. Pubmed PMID: 26963206.

[2]. Ashok V, Ganapathy D. A geometrical method to classify face forms. J Oral Biol Craniofac Res. 2019 Jul-Sep;9(3):232-235. Pubmed PMID: 31198677.

[3]. Balkenhol M, Wöstmann B, Rein C, Ferger P. Survival time of cast post and cores: a 10-year retrospective study. J Dent. 2007 Jan;35(1):50-8. Pubmed PMID: 16750593

[4]. Bastone EB, Freer TJ, McNamara JR. Epidemiology of dental trauma: a review of the literature. Aust Dent J. 2000 Mar;45(1):2-9. doi: 10.1111/ j.1834-7819.2000.tb00234.x. PMID: 10846265.

[5]. Chandrasekar R, Chandrasekhar S, Sundari KKS, Ravi P. Development and validation of a formula for objective assessment of cervical vertebral bone age. Prog Orthod. 2020 Oct 12;21(1):38. Pubmed PMID: 33043408.

[6]. Cheung W. A review of the management of endodontically treated teeth. Post, core and the final restoration. J Am Dent Assoc. 2005 May; 136(5):6119. Pubmed PMID: 15966648.

[7]. Cohen S, Burns RC. (2002) 'Pathways of the pulp 8th ed', St Louis Mosby, 2.

[8]. Ernesto Borgia DD, Rosario Barón DD, José Luis Borgia DD. Retrospective clinical study of 656 cast gold inlays/onlays in posterior teeth, in a 5 to 44year period: Analysis of results.

[9]. Ezhilarasan D. Oxidative stress is bane in chronic liver diseases: Clinical and experimental perspective. Arab J Gastroenterol. 2018 Jun;19(2):56-64. Pubmed PMID: 29853428.

[10]. Ezhilarasan D, Apoorva VS, Ashok Vardhan N. Syzygium cumini extract induced reactive oxygen species-mediated apoptosis in human oral squamous carcinoma cells. J Oral Pathol Med. 2019 Feb;48(2):115-121. Pubmed PMID: 30451321
[11]. Ezhilarasan D, Sokal E, Najimi M. Hepatic fibrosis: It is time to go with hepatic stellate cell-specific therapeutic targets. Hepatobiliary Pancreat Dis Int. 2018 Jun;17(3):192-197. Pubmed PMID: 29709350.

[12]. Gupta P, Ariga P, Deogade SC. Effect of Monopoly-coating Agent on the Surface Roughness of a Tissue Conditioner Subjected to Cleansing and Disinfection: A Contact Profilometric In vitro Study. Contemp Clin Dent. 2018 Jun;9(Suppl 1):S122-S126. Pubmed PMID: 29962776

[13]. Heydecke G, Butz F, Strub JR. Fracture strength and survival rate of endodontically treated maxillary incisors with approximal cavities after restoration with different post and core systems: an in-vitro study. J Dent. 2001 Aug;29(6):427-33. Pubmed PMID: 11520592.

[14]. Jain AR. Prevalence of partial edentulousness and treatment needs in rural population of South India. World J Dent. 2017 Jun;8(3):213-7.

[15]. Janani K, Palanivelu A, Sandhya R. Diagnostic accuracy of dental pulse oximeter with customized sensor holder, thermal test and electric pulp test for the evaluation of pulp vitality: an in vivo study. Brazilian dental science. 2020 Jan 31;23(1):8-p.

[16]. Jose J, Subbaiyan H. Different treatment modalities followed by dental practitioners for Ellis class 2 fracture-A questionnaire-based survey. The open dentistry journal. 2020 Feb 18;14(1).

[17]. Kane JJ, Burgess JO. Modification of the resistance form of amalgam coronal-radicular restorations. J Prosthet Dent. 1991 Apr;65(4):470-4. Pubmed PMID: 2066880.

[18]. Ke Y, Al Aboody MS, Alturaiki W, Alsagaby SA, Alfaiz FA, et al. Photosynthesized gold nanoparticles from Catharanthus roseus induces caspasemediated apoptosis in cervical cancer cells (HeLa). Artif Cells Nanomed Biotechnol. 2019 Dec;47(1):1938-1946. Pubmed PMID: 31099261.

[19]. Krishnan RP, Ramani P, Sherlin HJ, Sukumaran G, Ramasubramanian A Jayaraj G, Don KR, Santhanam A. Surgical Specimen Handover from Operation Theater to Laboratory: A Survey. Ann Maxillofac Surg. 2018 JulDec;8(2):234-238. Pubmed PMID: 30693238.

[20]. Manohar MP, Sharma S. A survey of the knowledge, attitude, and awareness about the principal choice of intracanal medicaments among the general dental practitioners and nonendodontic specialists. Indian J Dent Res. 2018 Nov-Dec;29(6):716-720. Pubmed PMID: 30588997.

[21]. Mathew MG, Samuel SR, Soni AJ, Roopa KB. Evaluation of adhesion of Streptococcus mutans, plaque accumulation on zirconia and stainless steel crowns, and surrounding gingival inflammation in primary molars: randomized controlled trial. Clin Oral Investig. 2020 Sep;24(9):3275-3280. Pubmed PMID: 31955271.

[22]. Noor SS. Chlorhexidine: Its properties and effects. Res J Pharm Technol. 2016;9(10):1755-60.

[23]. Padavala S, Sukumaran G. Molar Incisor Hypomineralization and Its Prevalence. Contemp Clin Dent. 2018 Sep;9(Suppl 2):S246-S250. Pubmed PMID: 30294152.

[24]. Palati S, Ramani P, Shrelin HJ, Sukumaran G, Ramasubramanian A, Don KR, Jayaraj G, Santhanam A. Knowledge, Attitude and practice survey on the perspective of oral lesions and dental health in geriatric patients residing in old age homes. Indian J Dent Res. 2020 Jan-Feb;31(1):22-25. Pubmed PMID: 32246676

[25]. Pandian KS, Krishnan S, Kumar SA. Angular photogrammetric analysis of the soft-tissue facial profile of Indian adults. Indian J Dent Res. 2018 MarApr;29(2):137-143. Pubmed PMID: 29652003.

[26]. Paramasivam A, Vijayashree Priyadharsini J, Raghunandhakumar S. N6adenosine methylation $(\mathrm{m} 6 \mathrm{~A})$ : a promising new molecular target in hypertension and cardiovascular diseases. Hypertens Res. 2020 Feb;43(2):153-154. doi: 10.1038/s41440-019-0338-z. Epub 2019 Oct 2. PMID: 31578458.

[27]. J PC, Marimuthu T, C K, Devadoss P, Kumar SM. Prevalence and measurement of anterior loop of the mandibular canal using CBCT: A cross sectional study. Clin Implant Dent Relat Res. 2018 Aug;20(4):531-534. Pubmed PMID: 29624863.

[28]. Peutzfeldt A, Sahafi A, Asmussen E. A survey of failed post-retained restorations. Clin Oral Investig. 2008 Mar;12(1):37-44. Pubmed PMID: 17636353.

[29]. Rajendran R, Kunjusankaran RN, Sandhya R, Anilkumar A, Santhosh R, Patil SR. Comparative evaluation of remineralizing potential of a paste containing bioactive glass and a topical cream containing casein phosphopeptide-amorphous calcium phosphate: An in vitro study. Pesquisa brasileira em odontopediatria e clinica integrada. 2019 Oct 10;19.

[30]. Ramadurai N, Gurunathan D, Samuel AV, Subramanian E, Rodrigues SJL. Effectiveness of 2\% Articaine as an anesthetic agent in children: randomized controlled trial. Clin Oral Investig. 2019 Sep;23(9):3543-3550. Pubmed PMID: 30552590 .

[31]. Ramamoorthi S, Nivedhitha MS, Divyanand MJ. Comparative evaluation of postoperative pain after using endodontic needle and EndoActivator during root canal irrigation: A randomised controlled trial. Aust Endod J. 2015 Aug;41(2):78-87. Pubmed PMID: 25195661. 
[32]. Ramamurthy JA, Mg V. Comparison of effect of Hiora mouthwash versus Chlorhexidine mouthwash in gingivitis patients: A clinical trial. Asian J Pharm Clin Res. 2018 Jul 7;11(7):84-8.

[33]. Ramanathan S, Solete P. Cone-beam Computed Tomography Evaluation of Root Canal Preparation using Various Rotary Instruments: An in vitro Study. J Contemp Dent Pract. 2015 Nov 1;16(11):869-72. Pubmed PMID: 26718293.

[34]. Ramesh A, Varghese S, Jayakumar ND, Malaiappan S. Comparative estimation of sulfiredoxin levels between chronic periodontitis and healthy patients - A case-control study. J Periodontol. 2018 Oct;89(10):1241-1248. Pubmed PMID: 30044495.

[35]. R H, Ramani P, Ramanathan A, R JM, S G, Ramasubramanian A, K M. CYP2 C9 polymorphism among patients with oral squamous cell carcinoma and its role in altering the metabolism of benzo[a]pyrene. Oral Surg Oral Med Oral Pathol Oral Radiol. 2020 Sep;130(3):306-312. Pubmed PMID: 32773350

[36]. Rosenstiel SF, Fujimoto J, Land MF. Contemporary Fixed Prosthodontics Mosby Elsevier. St Louis. 2001.

[37]. Samuel SR. Can 5-year-olds sensibly self-report the impact of developmental enamel defects on their quality of life? Int J Paediatr Dent. 2021 Mar;31(2):285-286. Pubmed PMID: 32416620.

[38]. Samuel SR, Acharya S, Rao JC. School Interventions-based Prevention of Early-Childhood Caries among 3-5-year-old children from very low socioeconomic status: Two-year randomized trial. J Public Health Dent. 2020 Jan;80(1):51-60. Pubmed PMID: 31710096.

[39]. Shaikh A, Mandke L, Padhye L. Fabrication of cast post and core by a modified indirect procedure and postcementation using a novel technique. Indian Journal of Oral Health and Research. 2017 Jul 1;3(2):91.

[40]. Shashikala K, Sharma SO. Clinical and radiological evaluation of cast metal and quartz fiber posts in endodontically restored teeth. Endodontology. 2011 Dec;3:37-46.

[41]. Siddique R, Sureshbabu NM, Somasundaram J, Jacob B, Selvam D. Quali- tative and quantitative analysis of precipitate formation following interaction of chlorhexidine with sodium hypochlorite, neem, and tulsi. J Conserv Dent. 2019 Jan-Feb;22(1):40-47. Pubmed PMID: 30820081.

[42]. Sridharan G, Ramani P, Patankar S, Vijayaraghavan R. Evaluation of salivary metabolomics in oral leukoplakia and oral squamous cell carcinoma. J Oral Pathol Med. 2019 Apr;48(4):299-306. Pubmed PMID: 30714209.

[43]. Teja KV, Ramesh S. Shape optimal and clean more. Saudi Endodontic Journal. 2019 Sep 1;9(3):235.

[44]. Teja KV, Ramesh S, Priya V. Regulation of matrix metalloproteinase-3 gene expression in inflammation: A molecular study. J Conserv Dent. 2018 NovDec;21(6):592-596. Pubmed PMID: 30546201.

[45]. Varghese SS, Ramesh A, Veeraiyan DN. Blended Module-Based Teaching in Biostatistics and Research Methodology: A Retrospective Study with Postgraduate Dental Students. J Dent Educ. 2019 Apr;83(4):445-450. Pubmed PMID: 30745352.

[46]. Gajjela RS, Satish RK, Sajjan GS, Varma KM, Rambabu T, Vijaya Lakshmi BH. Comparative evaluation of chlorhexidine, grape seed extract, riboflavin/ chitosan modification on microtensile bond strength of composite resin to dentin after polymerase chain reaction thermocycling: An in vitro study. J Conserv Dent. 2017 Mar-Apr;20(2):120-124. Pubmed PMID: 28855760.

[47]. Vijayashree Priyadharsini J. In silico validation of the non-antibiotic drugs acetaminophen and ibuprofen as antibacterial agents against red complex pathogens. J Periodontol. 2019 Dec;90(12):1441-1448. Pubmed PMID: 31257588.

[48]. Vijayashree Priyadharsini J, Smiline Girija AS, Paramasivam A. In silico analysis of virulence genes in an emerging dental pathogen A. baumannii and related species. Arch Oral Biol. 2018 Oct;94:93-98. Pubmed PMID: 30015217.

[49]. Vikram NR, Prabhakar R, Kumar SA, Karthikeyan MK, Saravanan R. Ball Headed Mini Implant. J Clin Diagn Res. 2017 Jan;11(1):ZL02-ZL03. Pubmed PMID: 28274084 . 